\title{
Effects of nisin on Staphylococcus aureus count and physicochemical properties of Minas Frescal cheese
}

\author{
Bruna A. Felicio, ${ }^{*}$ Maximiliano S. Pinto, ${ }^{* 1}$ Francielly S. Oliveira, ${ }^{*}$ Marcus W. Lempk, ${ }^{*}$ Ana Clarissa S. Pires, $\dagger$ \\ and Carini A. Lelis† \\ *Institute of Agricultural Sciences, Federal University of Minas Gerais, Montes Claros, MG 39404-547, Brazil \\ †Department of Food Technology, Federal University of Viçosa, Viçosa, MG 36570-000, Brazil
}

\begin{abstract}
The aim of this work was to evaluate the effects of nisin on in vitro and in situ Staphylococcus aureus counts. For in vitro experiment, milk was inoculated with 5.0 $\log \mathrm{cfu} \cdot \mathrm{mL}^{-1}$ of $S$. aureus and nisin was added at concentrations of $0,100,200,400$, and $500 \mathrm{IU} \mathrm{mL}^{-1}$. The main effect of the bacteriocin was lag phase extension from $0 \mathrm{~h}$, for 0 and $100 \mathrm{IU} \cdot \mathrm{mL}^{-1}$ to $8 \mathrm{~h}$, when 200,400 , and $500 \mathrm{IU} \cdot \mathrm{mL}^{-1}$ of nisin were used; however, $\log$ phase was not affected. Microbial growth rate was found to be exponential and around $0.11 \log \mathrm{cfu} \cdot \mathrm{mL}^{-1} \cdot \mathrm{h}^{-1}$ for all treatments. For in situ experiments, 0, 400, and 500 $\mathrm{IU} \cdot \mathrm{mL}^{-1}$ of nisin were directly added to pasteurized milk previously inoculated with $5.0 \mathrm{log} \mathrm{cfu} \cdot \mathrm{g}^{-1}$ of $S$. aureus. Milk, curd, and whey were analyzed to $S$. aureus counts. Nisin at concentration of $500 \mathrm{IU} \cdot \mathrm{mL}^{-1}$ was able to reduce $S$. aureus count in curd and whey, demonstrating nisin partition between both phases. Throughout storage at $4^{\circ} \mathrm{C}, S$. aureus count increased for all treatments, but the bacterial grew slower when nisin was added in both concentrations, maintaining $S$. aureus count about $1.5 \log$ cycles lower than the control, despite abusive initial $S$. aureus count. Therefore, nisin seems to play an important role in reducing $S$. aureus initial count in cheese made with highly contaminated milk. Nisin showed potential to be used as an additional, important hurdle to improve Minas Frescal cheese safety, without replacing good manufacturing practices.
\end{abstract}

Key words: bacteriocin, bacterial growth, high moisture cheese, milk, food poisoning

\section{INTRODUCTION}

Minas Frescal cheese is widely consumed in Brazil. It is a fresh, soft white cheese produced via enzymatic coagulation, resulting in a preservative-free cheese having high water activity, low salt content, and $\mathrm{pH}$ higher

Received March 2, 2015.

Accepted March 29, 2015.

${ }^{1}$ Corresponding author: maxonze@yahoo.com.br than 5.0, and that does not undergo maturation. These features make Minas Frescal cheese highly perishable and its shelf life remarkably short, even under refrigeration (Silva et al., 2003; Malheiros et al., 2012; Magenis et al., 2014).

The physicochemical characteristics of Minas Frescal cheese increase the potential risk of pathogenic bacteria incidence, including Salmonella spp., Listeria monocytogenes, Escherichia coli, and Staphylococcus aureus (Carvalho et al., 2007). Staphylococcal food poisoning is often related to cheese consumption due to the presence of enterotoxins (Hennekinne et al., 2012), which in turn are probably caused by excessive human manipulation during cheese production.

The most efficient way of reducing the initial milk contamination and, consequently, producing a safer cheese is by improving the hygienic conditions during milking and cheese production (Poli et al., 2007). However, these practices have not been enough to ensure Minas Frescal cheese quality and safety because many studies have associated this cheese with food poisoning (Silva et al., 2003; Carvalho et al., 2007; André et al., 2008; Malheiros et al., 2012; Magenis et al., 2014).

Some studies have shown that bacteriocins can act as an additional hurdle to reduce pathogenic bacteria contamination in cheeses (Pinto et al., 2011; Malheiros et al., 2012). Bacteriocin action mechanism is particularly interesting when compared with traditional antibiotics due to their strong antibacterial activity against a broad microorganism spectrum and to the low bacterial resistance rates (Malheiros et al., 2012; Tong et al., 2014). Nisin, the most studied bacteriocin, is generally regarded as safe (GRAS) by the Joint Food and Agriculture Organization/World Health Organization (FAO/WHO) Expert Committee on Food Additives. Nisin is a 34 amino acid peptide produced by Lactococcus lactis ssp. lactis, and it is antimicrobially effective against a wide range of gram-positive bacteria (Liu et al., 2015).

Many studies have shown that nisin is effective against Staphylococcus sp. (Hamama et al., 2002; Pinto et al., 2011; Pimentel-Filho et al., 2014; Zhao et al., 
2014; Liu et al., 2015). However, to the best of our knowledge, few data are available regarding the effect of nisin against $S$. aureus in Minas Frescal cheese, which is a fresh, highly manipulated product and, thus, an important vehicle for the staphylococcal enterotoxin.

Therefore, with the aim of contributing to Minas Frescal cheese safety and extending its shelf life, the goal of this work was to evaluate the inhibitory effect of different nisin concentrations against $S$. aureus inoculated in Minas Frescal cheese during $30 \mathrm{~d}$ of storage.

\section{MATERIALS AND METHODS}

\section{Nisin Preparation}

For in vitro experiments, commercial nisin (Nisaplin, Danisco Brasil Ltda, Pirapozinho, Brazil) suspensions at $2.5 \%(\mathrm{wt} / \mathrm{wt})$ in reconstituted $(10 \% \mathrm{wt} / \mathrm{vol})$ skim milk (RSM). For in situ experiments, nisin was directly added to milk during cheese manufacturing.

\section{Culture and Growth Conditions}

Staphylococcus aureus (ATCC 6538) cultures were used in this study. The stock culture was maintained at $-80^{\circ} \mathrm{C}$ in brain heart infusion $(\mathbf{B H I})$ broth (Difco, Becton, Dickinson and Company, Franklin Lakes, NJ) containing $10 \%$ (vol/vol) of glycerol. Stock cultures were recovered in BHI broth and subsequently subcultured thrice in $\mathrm{BHI}$ at $37^{\circ} \mathrm{C}$ for $24 \mathrm{~h}$.

\section{Nisin In Vitro Antagonistic Effect Against S. aureus}

Staphylococcus aureus was added to nisin suspensions, prepared in RSM at 10\%, at concentrations of 0,100 , 200,400 , and $500 \mathrm{IU} \cdot \mathrm{mL}^{-1}$ to obtain an initial count of $1 \times 10^{5} \mathrm{cfu} \cdot \mathrm{mL}^{-1}$. Systems were incubated at $37 \pm 2^{\circ} \mathrm{C}$ during $24 \mathrm{~h}$ and $S$. aureus was counted throughout this period by using Petrifilm 3M Rapid $S$. aureus Count Plates (AOAC International, 2003; method 981.15). Previous studies have demonstrated that Petrifilm is suitable for $S$. aureus count in dairy products (Viçosa et al., 2010).

\section{Nisin Antagonistic Effect Against S. aureus Inoculated in Minas Frescal Cheese}

To evaluate nisin in situ effect on $S$. aureus, Minas Frescal cheese was produced with pasteurized milk containing $3.0 \%$ (wt/wt) of fat and added by commercial rennet and sodium chloride at $2.0 \%$ (wt/wt), according to the flowchart illustrated in Figure 1. Good manufacturing practices were followed to avoid cheese contamination.
Staphylococcus aureus was added to pasteurized milk to obtain an abusive initial count of $1 \times 10^{5} \mathrm{cfu} \cdot \mathrm{mL}^{-1}$. Based upon in vitro tests, nisin was added at concentrations of 400 and $500 \mathrm{IU} \cdot \mathrm{mL}^{-1}$. Nisin was not added to control milk.

Microbiological analyses were carried out in milk, whey, and curd during cheese production as well as in cheese after $1,7,14,21$, and $30 \mathrm{~d}$ of storage. For each analysis, 25-g (or $25 \mathrm{~mL}$ ) samples were diluted in $225 \mathrm{~mL}$ of $0.2 \%$ (wt/vol) peptone water. Staphylococcus aureus was counted in Petrifilm 3M Rapid S. aureus Count Plates (AOAC 981.15), according to the manufacturer's recommendations.

\section{Data Analysis}

The experiments were carried out 3 times in a completely randomized design. The decimal logarithms of $S$. aureus counts were evaluated by ANOVA, using the Tukey test at a significance level of $P<0.05$ to compare mean values. The analyses were performed using the Software Analysis and Experimentation Group, version 8.0 (SAEG, Viçosa, Minas Gerais, Brazil).

\section{RESULTS AND DISCUSSION}

\section{Nisin In Vitro Effect Against S. aureus}

Culture medium composition is known to influence antimicrobial tests (Huys et al., 2002). Therefore, we chose reconstituted ( $10 \% \mathrm{wt} / \mathrm{wt})$ skim milk (RSM) to investigate the nisin in vitro effect on $S$. aureus. Reconstituted skim milk is rich in proteins that can interact with nisin, reducing its effect. Inhibition of $S$. aureus inoculated in milk containing different nisin concentrations is shown in Figure 2.

In the absence of nisin, $S$. aureus grew immediately without a lag phase and reached a maximum population density (MPD) of $7.8 \log \mathrm{cfu} \cdot \mathrm{mL}^{-1}$ during $24 \mathrm{~h}$ in $\mathrm{RSM}(\mathrm{pH}=6.5)$. When $100 \mathrm{IU} \cdot \mathrm{mL}^{-1}$ was added to RSM, a similar behavior was observed $(P>0.05)$. Pinto et al. (2011) also did not confirm the effect of low nisin concentration $\left(100 \mathrm{IU} \cdot \mathrm{mL}^{-1}\right)$ against $S$. aureus in RSM (12\% wt/wt).

Nisin concentration of $200 \mathrm{IU} \cdot \mathrm{mL}^{-1}$, however, was effective against $S$. aureus as lag phase was increased to 8 h. After this adaptation period, cells grew and achieved a MPD of $7.6 \log \mathrm{cfu} \cdot \mathrm{mL}^{-1}$ during $36 \mathrm{~h}$. This result demonstrates that nisin was effective both in increasing the $S$. aureus lag phase and in reducing bacteria growth in RSM even at the optimum inoculation temperature.

When nisin concentration was enhanced to 400 and $500 \mathrm{IU} \cdot \mathrm{mL}^{-1}$, different $S$. aureus growth patterns were observed if compared with lower nisin concentrations. 


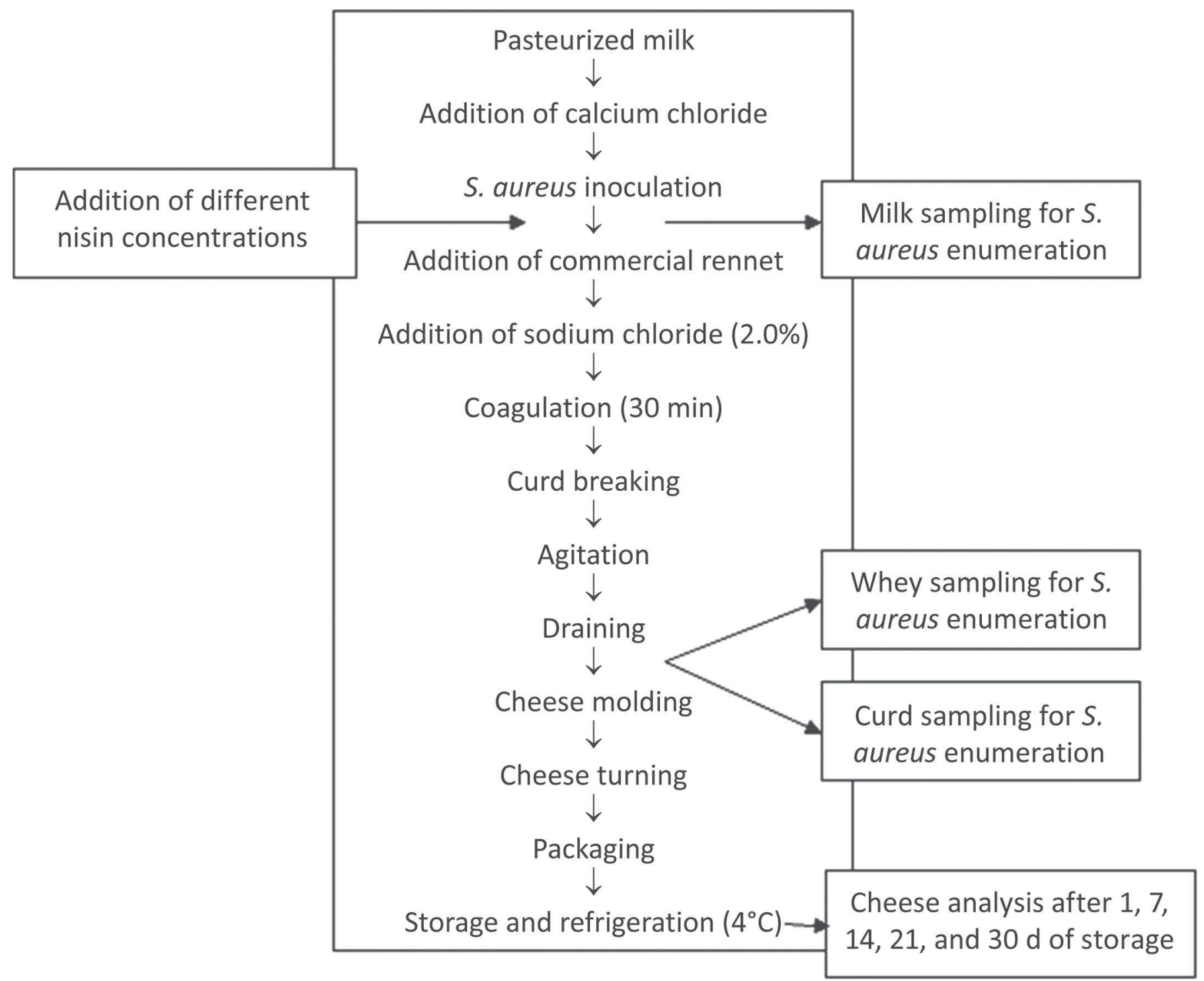

Figure 1. Schematic flowchart of Minas Frescal cheese production.

Initially, a reduction of $1.3 \log$ cycles in bacteria count occurred until $8 \mathrm{~h}$ of incubation, showing evidence of nisin bactericidal effect. However, after 16 h, S. aureus achieved a count that compensated the initial reduction caused by nisin, and MPD $\left(7.2 \mathrm{log} \mathrm{cfu} \cdot \mathrm{mL}^{-1}\right)$ was reached until 36 h. For control and all nisin concentrations, $\log$ phase showed a similar behavior $(P>0.05)$ and the exponential microbial growth rate was almost the same (around $0.11 \log \mathrm{cfu} \cdot \mathrm{mL}^{-1} \cdot \mathrm{h}^{-1}$ ). These results indicate that the main nisin effect is lag phase extension, which is in accordance with a previous report (Kiss et al., 2007).

In another work, $10,000 \mathrm{IU} \cdot \mathrm{mL}^{-1}$ of nisin was able to reduce $S$. aureus counts by $4.68 \mathrm{log} \mathrm{cfu} \cdot \mathrm{mL}^{-1}$ in milk after $4 \mathrm{~h}$ of incubation at $37^{\circ} \mathrm{C}$, followed by bacteria surviving cell regrowth after $24 \mathrm{~h}$. This behavior was attributed to the presence of nisin-resistant bacteria (Arqués et al., 2011). Grisi and Gorlach-Lira (2005) used a nisin concentration close to that used in the present experiment and found that this bacteriocin was bacteriostatic up to $8 \mathrm{~h}$ for $S$. aureus growth in BHI broth. However, after the lag period, the multiplication rate was similar to that in the absence of nisin, which is the behavior also associated with resistant cells. On the other hand, according to Gallo et al. (2007), the survivors are not necessarily resistant to nisin. They may also have escaped from nisin action due to insufficient bacteriocin availability.

Because only 400 and $500 \mathrm{IU} \cdot \mathrm{mL}^{-1}$ of nisin demonstrated potential to inhibit $S$. aureus mainly by in- 


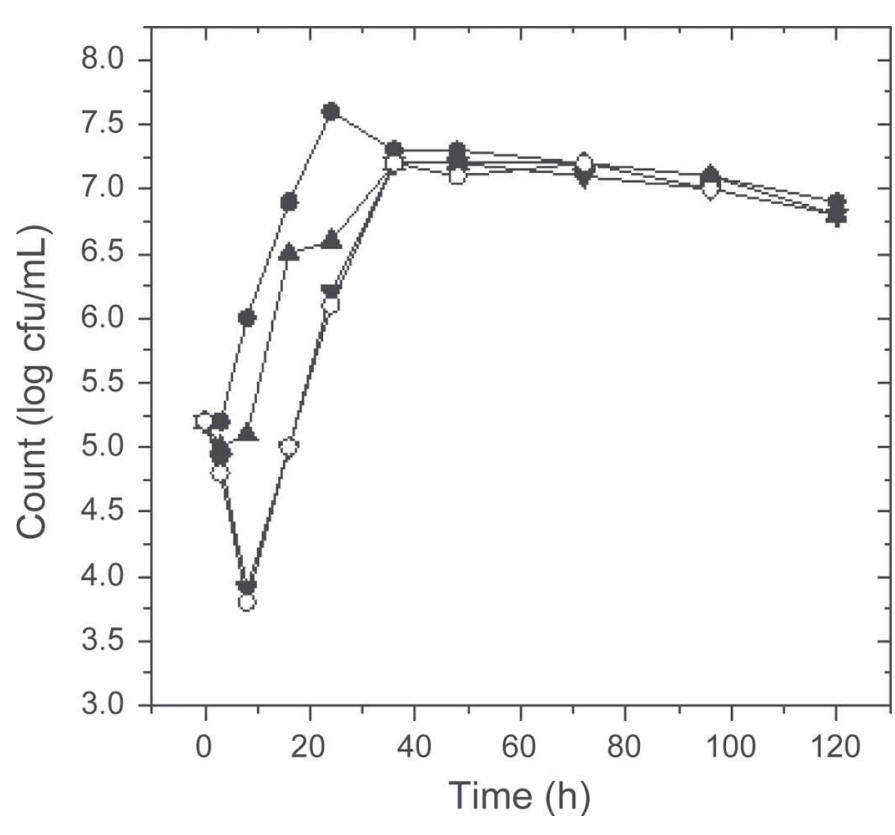

Figure 2. Activity of different nisin levels against Staphylococcus aureus (initial count: $1 \times 10^{5} \mathrm{cfu} \cdot \mathrm{mL}^{-1}$ ) inoculated in reconstituted (10\%) skimmed milk: $0(\mathbf{\square}), 100(\bullet), 200(\mathbf{\Delta}), 400(\mathbf{v})$, or $500(\bigcirc)$ $\mathrm{IU} \cdot \mathrm{mL}^{-1}$.

creasing its lag phase, we selected these concentrations to apply in Minas Frescal cheese production (in situ experiment). It is worth emphasizing that both nisin concentrations are in agreement with the Food and Agriculture Organization/World Health Organization Codex Committee on milk and milk products, which accepted nisin as a food additive for processed cheese at a concentration of $12.5 \mathrm{mg}$ of pure nisin $/ \mathrm{kg}$ of product (Ross et al., 2002).

\section{S. aureus Count in Milk, Whey, and Curd During Minas Frescal Cheese Production}

The presence of different constituents as well as the production steps may affect both bacteria cell and bacteriocin distributions when milk is curdled into curd and whey. It is very important to consider nisin distribution because its presence in curd is an indicative of its effect against $S$. aureus and, as a consequence, of cheese shelf life. Nisin had been used to prolong cheese shelf life in previous studies (Kykkidou et al., 2007; Mitra et al., 2010). Table 1 presents the nisin effect against $S$. aureus in milk, whey, and curd.

In all production steps, $S$. aureus count was higher when nisin was absent. No difference $(P>0.05)$ was found between nisin concentrations of 400 and 500 $\mathrm{UI} \cdot \mathrm{mL}^{-1}$, concentrations that led to reductions of 0.75 and $0.91 \log \mathrm{cfu} \cdot \mathrm{mL}^{-1}$, respectively, on S. aureus count. Results higher than ours were found for $400 \mathrm{IU} \cdot \mathrm{mL}^{-1}$ of nisin, which was able to inhibit $26.2 \%$ of $S$. aureus in raw milk. However, the initial count studied was lower $\left(6.03 \times 10^{2} \mathrm{cfu} \cdot \mathrm{mL}^{-1}\right)$ than that used in our experiment (Takahashi et al., 2003).

Nisin concentration affected $(P<0.05) S$. aureus count in whey and curd, provided the reduction of approximately $2.0 \mathrm{log} \mathrm{cfu} \cdot \mathrm{g}^{-1}$ led by $500 \mathrm{IU} \cdot \mathrm{mL}^{-1}$ of nisin. This confirmed the nisin bactericidal effect against $S$. aureus in cheese. It is important to emphasize that even though part of the nisin added to milk diffused to whey, the remaining nisin in curd was enough to achieve $S$. aureus counts lower than that required by Brazilian legislation for Minas Frescal cheese $\left(2.7 \mathrm{log} \mathrm{cfu} \cdot \mathrm{g}^{-1}\right)$. Pinto et al. (2011) also verified the nisin effect on $S$. aureus on Minas Traditional cheese curd, contributing to a low initial count.

\section{S. aureus Count in Minas Frescal Cheese}

Minas Frescal cheese is classified as a high moisture cheese. It has low salt content and $\mathrm{pH}$ near 6.0 (Carvalho et al., 2007). Therefore, it is expected that $S$. aureus count increases during storage. Figure 3 shows the nisin effect on $S$. aureus growth throughout Minas Frescal cheese storage.

After only $1 \mathrm{~d}$ of storage, $S$. aureus counts in all treatments were higher than that established by Brazilian legislation, indicating that cheese molding, turning, and packaging steps are critical to bacterial growth.

Although $S$. aureus count increased during storage, nisin inhibited bacterial growth in Minas Frescal cheese. Even after $30 \mathrm{~d}, S$. aureus count was lower for both nisin concentrations, which were not different $(P$ $>0.05)$, indicating that the bacteriocin was effective against this microorganism in the cheese matrix. It is known that nisin interacts with some food constituents such as proteins and lipids, reducing nisin action against bacterial development (Aly et al., 2012). Additionally, for nisin to be effective, it needs to diffuse through the medium and reach bacterial colonies, and cheese matrix may hamper nisin diffusion, decreasing its efficacy. In this experiment, we found that cheese

Table 1. Staphylococcus aureus count $\left(\log \mathrm{cfu} \cdot \mathrm{mL}^{-1}\right)$ as a function of nisin concentration in different steps of Minas Frescal cheese production

\begin{tabular}{lccc}
\hline & \multicolumn{3}{c}{ Nisin concentration, ${\mathrm{IU} \cdot \mathrm{g}^{-1} \text { or } \mathrm{mL}^{-1}}$} \\
\cline { 2 - 4 } Step & 0 & 400 & 500 \\
\hline Milk & $6.30^{\mathrm{a}}$ & $5.55^{\mathrm{b}}$ & $5.39^{\mathrm{b}}$ \\
Whey & $5.48^{\mathrm{a}}$ & $4.50^{\mathrm{b}}$ & $3.40^{\mathrm{c}}$ \\
Curd & $4.59^{\mathrm{a}}$ & $2.91^{\mathrm{b}}$ & $2.49^{\mathrm{c}}$ \\
\hline
\end{tabular}

${ }^{\mathrm{a}-\mathrm{c}}$ For each step, mean values followed by different letters within a row were different $(P<0.05)$ as indicated by Tukey test. 


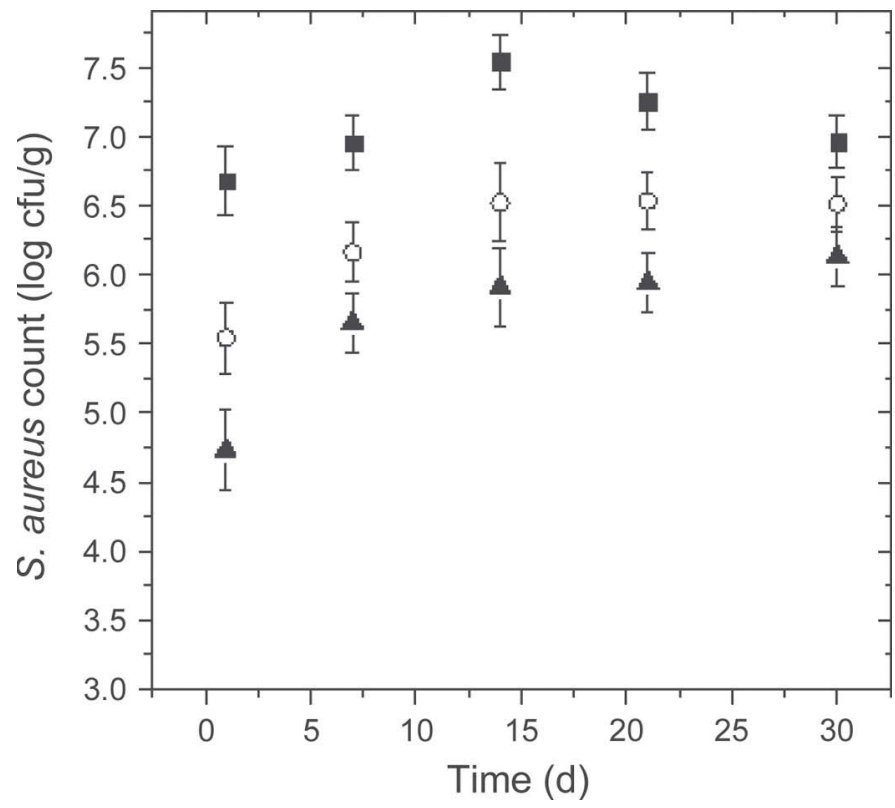

Figure 3. Staphylococcus aureus growth in Minas Frescal cheese as a function of storage time at $4{ }^{\circ} \mathrm{C}$, in the presence of $0(\mathbf{\square}), 400(\mathrm{O})$, or $500(\boldsymbol{\Delta}) \mathrm{IU} \cdot \mathrm{mL}^{-1}$ of nisin.

protein-lipid 3-dimensional structure did not avoid nisin action on bacteria.

In spite of nisin action, the main contribution of bacteriocin addition to Minas Frescal cheese seems to be the reduction on initial $S$. aureus count. It was clear that bacterial count increased during storage, but the growth was slower in cheese samples containing bacteriocin. Staphylococcus aureus growth could be attributed to the high $\mathrm{pH}$ of Minas Frescal cheese (which ranged from 6.6 to 5.9 during storage), given that nisin is more effective in low pH (Tong et al., 2014). Nisin could also have interacted with casein (Aly et al., 2012), resulting in less bacteriocin available to inhibit bacterial growth. Additionally, it is known that variant resistant cells can appear from nisin-sensitive strains (Garde et al., 2004). Therefore, some $S$. aureus cells could have survived and been selected, leading to reduced nisin effect during cheese storage.

In another study, nisin at $600 \mathrm{IU} \cdot \mathrm{g}^{-1}$ combined with bovicin was also used in Minas Frescal cheese having an initial $S$. aureus count of $10^{4} \mathrm{cfu} \cdot \mathrm{g}^{-1}$. This bacteriocin mix was able to reduce only 1 log cycle until 15 d of storage at $4^{\circ} \mathrm{C}$. After this period, bacteria regrew (Pimentel-Filho et al., 2014).

Our results clearly demonstrate that nisin could be an important tool to avoid enterotoxin production in Minas Frescal cheese, especially if initial S. aureus count is low. Therefore, nisin should be used as an additional hurdle in Minas Frescal cheese production, but it cannot replace good manufacturing practices.

\section{CONCLUSIONS}

Nisin was shown to be effective in controlling $S$. aureus growth both in milk and Minas Frescal cheese. During cheese production, this bacteriocin was distributed either in whey or in curd. Nisin seems to increase the lag phase of $S$. aureus inoculated in milk. Higher nisin concentrations (400 and $500 \mathrm{IU} \cdot \mathrm{mL}^{-1}$ ) reduced $S$. aureus growth in Minas Frescal cheese, but the main effect was the reduction on $S$. aureus initial count in the tested cheese. Nisin has potential to be used as an additional hurdle to improve Minas Frescal cheese safety and preservation. It should be used together with good manufacturing practices to achieve the best outcome.

\section{ACKNOWLEDGMENTS}

The authors thank FAPEMIG (Fundação de Amparo à Pesquisa do Estado de Minas Gerias, Brazil) and CNPq (Conselho Nacional de Desenvolvimento Científico e Tecnológico, Brazil) for the financial support. M. W. L. and C. A. L. thank CAPES for scholarship.

\section{REFERENCES}

Aly, S., J. Floury, M. Piot, S. Lortal, and S. Jeanson. 2012. The efficacy of nisin can drastically vary when produced in situ in model cheeses. Food Microbiol. 32:185-190. http://dx.doi.org/10.1016/j. fm.2012.06.001

André, M. C. D. P. B., M. R. H. Campos, L. J. Borges, A. Kipnis, F. C. Pimenta, and Á. B. Serafini. 2008. Comparison of Staphylococcus aureus isolates from food handlers, raw bovine milk and Minas Frescal cheese by antibiogram and pulsed-field gel electrophoresis following SmaI digestion. Food Contr. 19:200-207. http://dx.doi. org/10.1016/j.foodcont.2007.03.010.

AOAC. 2003. Official Methods of Analysis. 2nd rev. 17th ed. AOAC International, Gaithersburg, MD.

Arqués, J. L., E. Rodríguez, M. Nuñez, and M. Medina. 2011. Combined effect of reuterin and lactic acid bacteria bacteriocins on the inactivation of food-borne pathogens in milk. Food Contr. 22:457-461. http://dx.doi.org/10.1016/j.foodcont.2010.09.027.

Carvalho, J. D. G., W. H. Viotto, and A. Y. Kuaye. 2007. The quality of Minas Frescal cheese produced by different technological processes. Food Contr. 18:262-267. http://dx.doi.org/10.1016/j. foodcont.2005.10.005.

Gallo, L. I., A. M. R. Pilosof, and R. J. Jagus. 2007. Effective control of Listeria innocua by combination of nisin, $\mathrm{pH}$ and low temperature in liquid cheese whey. Food Contr. 18:1086-1092. http:// dx.doi.org/10.1016/j.foodcont.2006.07.009.

Garde, S., M. Avila, M. Medina, and M. Nuñez. 2004. Fast induction of nisin resistance in Streptococcus thermophilus INIA 463 during growth in milk. Int. J. Food Microbiol. 96:165-172. http://dx.doi. org/10.1016/j.ijfoodmicro.2004.03.023.

Grisi, T. C. S. L., and K. Gorlach-Lira. 2005. Action of nisin and high $\mathrm{pH}$ on growth of Staphylococcus aureus and Salmonella spp. in pure culture and in the meat of land crab (Ucides cordatus). Braz. J. Microbiol. 36:151-156. http://dx.doi.org/10.1590/S151783822005000200010.

Hamama, A., N. El Hankouri, and M. El Ayadi. 2002. Fate of enterotoxigenic Staphylococcus aureus in the presence of nisin-producing Lactococcus lactis strain during manufacture of Jben, a Moroccan traditional fresh cheese. Int. Dairy J. 12:933-938. http://dx.doi. org/10.1016/S0958-6946(02)00113-9. 
Hennekinne, J.-A., M.-L. De Buyser, and S. Dragacci. 2012. Staphylococcus aureus and its food poisoning toxins: Characterization and outbreak investigation. FEMS Microbiol. Rev. 36:815-836. http://dx.doi.org/10.1111/j.1574-6976.2011.00311.x.

Huys, G., K. D. Haene, and J. Swings. 2002. Influence of the culture medium on antibiotic susceptibility testing of food-associated lactic acid bacteria with the agar overlay disc diffusion method. Lett. Appl. Microbiol. 34:402-406.

Kiss, I. F., K. Márialigeti, E. Zukál, and J. Makk. 2007. Method for measurement of antibacterial activity of nisin. Bull. USAMV-CN 64:3-8.

Kykkidou, S., N. Pournis, O. K. Kostoula, and I. N. Savvaidis. 2007. Effects of treatment with nisin on the microbial flora and sensory properties of a Greek soft acid-curd cheese stored aerobically at $4^{\circ} \mathrm{C}$. Int. Dairy J. 17:1254-1258. http://dx.doi.org/10.1016/j. idairyj.2007.02.006.

Liu, H., H. Pei, Z. Han, G. Feng, and D. Li. 2015. The antimicrobial effects and synergistic antibacterial mechanism of the combination of $\varepsilon$-Polylysine and nisin against Bacillus subtilis. Food Contr. 47:444-450. http://dx.doi.org/10.1016/j.foodcont.2014.07.050.

Magenis, R. B., E. S. Prudêncio, C. B. Fritzen-Freire, M. P. Stephan, A. Silvio do Egito, and H. Daguer. 2014. Rheological, physicochemical and authenticity assessment of Minas Frescal cheese. Food Contr. 45:22-28. http://dx.doi.org/10.1016/j.foodcont.2014.04.012.

Malheiros, P. D. S., V. Sant'Anna, M. D. S. Barbosa, A. Brandelli, and B. D. G. D. M. Franco. 2012. Effect of liposome-encapsulated nisin and bacteriocin-like substance P34 on Listeria monocytogenes growth in Minas frescal cheese. Int. J. Food Microbiol. 156:272277. http://dx.doi.org/10.1016/j.ijfoodmicro.2012.04.004.

Mitra, S., P. K. Chakrabartty, and S. R. Biswas. 2010. Potential production and preservation of dahi by Lactococcus lactis W8, a nisinproducing strain. LWT Food Sci. Technol. (Campinas.) 43:337342. http://dx.doi.org/10.1016/j.lwt.2009.08.013.

Pimentel-Filho, N. D. J., M. C. D. F. Martins, G. B. Nogueira, H. C. Mantovani, and M. C. D. Vanetti. 2014. Bovicin HC5 and nisin reduce Staphylococcus aureus adhesion to polystyrene and change the hydrophobicity profile and Gibbs free energy of adhesion.
Int. J. Food Microbiol. 190:1-8. http://dx.doi.org/10.1016/j. ijfoodmicro.2014.08.004.

Pinto, M. S., A. F. de Carvalho, A. C. dos Santos Pires, A. A. Campos Souza, P. H. Fonseca da Silva, D. Sobral, J. C. J. de Paula, and A. de Lima Santos. 2011. The effects of nisin on Staphylococcus aureus count and the physicochemical properties of traditional Minas Serro cheese. Int. Dairy J. 21:90-96. http://dx.doi.org/10.1016/j. idairyj.2010.08.001.

Poli, A., E. Guglielmini, S. Sembeni, M. Spiazzi, F. Dellaglio, F. Rossi, and S. Torriani. 2007. Detection of Staphylococcus aureus and enterotoxin genotype diversity in Monte Veronese, a Protected Designation of Origin Italian cheese. Lett. Appl. Microbiol. 45:529 534. http://dx.doi.org/10.1111/j.1472-765X.2007.02224.x.

Ross, R. P., S. Morgan, and C. Hill. 2002. Preservation and fermentation: Past, present and future. Int. J. Food Microbiol. 79:3-16.

Silva, I. M. M., R. C. C. Almeida, M. A. O. Alves, and P. F. Almeida. 2003. Occurrence of Listeria spp. in critical control points and the environment of Minas Frescal cheese processing. Int. J. Food Microbiol. 81:241-248.

Takahashi, H. T., L. H. S. Miglioranza, and R. J. H. C. Gómez. 2003. Aplicação da nisina em leite cru para inibição de Staphylococcus aureus enterotoxigênicos. Rev. do Inst. Laticínios Cândido Tostes 58:78-84.

Tong, Z., L. Ni, and J. Ling. 2014. Antibacterial peptide nisin: A potential role in the inhibition of oral pathogenic bacteria. Peptides 60:32-40. http://dx.doi.org/10.1016/j.peptides.2014.07.020.

Viçosa, G. N., P. M. Moraes, A. K. Yamazi, and L. A. Nero. 2010. Enumeration of coagulase and thermonuclease-positive Staphylococcus spp. in raw milk and fresh soft cheese: An evaluation of Baird-Parker agar, Rabbit Plasma Fibrinogen agar and the Petrifilm Staph Express count system. Food Microbiol. 27:447-452. http://dx.doi.org/10.1016/j.fm.2009.12.007.

Zhao, X., Z. Liu, W. Li, X. Li, C. Shi, R. Meng, W. Cheng, K. Jin, Z. Yang, X. Shi, N. Guo, and L. Yu. 2014. In vitro synergy of nisin and coenzyme Q0 against Staphylococcus aureus. Food Contr. 46:368-373. http://dx.doi.org/10.1016/j.foodcont.2014.05.051. 